\title{
Public Administration Transparency in E-government at Local Level of Czech Government
}

\author{
Eva Ardielli \\ VSB - Technical University of Ostrava, Faculty of Economics, Sokolská 33, Ostrava, Czech Republic
}

\begin{abstract}
Transparency is currently required as an essential element of public administration functioning. It supports quality, effectiveness and economy of administration both at the central and the local level of government. Transparency is currently also supported by modernization trends in public administration utilizing an implementation of information technologies and open access to information. Worldwide e-government plays a key role in the modernization efforts of public administration. It is the effective tool to transform the public administration and public services towards greater transparency, information availability and participation in decision-making process. The paper focuses on the analysis of transparency principle application on the local level of government in the Czech Republic. It is based on the evaluation of transparency in local decision-making, information availability and participation possibility. The availability of selected information was analyzed on selected local municipal websites in the MoravianSilesian region in the year of 2014. The aim of the paper is to assess information disclosure on official municipal websites, especially offering and availability of selected information and the rate of information availability on monitored municipal websites.
\end{abstract}

Keywords: Public administration, Transparency, Evaluation, E-government, Web sites

\section{Introduction}

Transparency plays a significant role in the contemporary trend of public administration modernization. It is one of the principles of Good Governance, which was first defined in 1999 by SIGMA organization (OECD, 1999). Good Governance principles originated from the experience made across different European countries with diverse systems of public administration. Currently, they are considered as a basis of efficient public administration in democratic states. As stated in Marek (2006), the principle of transparency implies an open and transparent public administration that is essential for the protection of the public interest and reduction of corruption.

Transparency in public administration is currently significantly supported by the entry of modern technologies (Information and Communication Technologies) in this sector. One suitable means which allows better public access to information and greater transparency in decision-making is the development of e-government (Gupta et al., 2008). Egovernment belongs to important current trends in public administration and it is also considered as the important tool for its modernization. E-government provides significant opportunities to transform the public administration towards greater transparency, openness and information availability. In addition, as stated in Vaníček (2011), e-government (for example on-line services or electronic processing of applications) is helping to eliminate corruption because of the avoiding of personal contact of the subjects. Another important trend of contemporary e-government is the development of e-participation. This is the development of innovative electronic tools that allow citizens to involve actively in decision-making processes of government.

Interpretation of the term "e-government" is quite broad and divergent. Generally, e-government means using information and communication technologies in a way of government transformation for the purpose of increasing transparency, availability, effectiveness and accountability, as stated in Michel (2005), Gil-García and Helbig (2006). According to European Commission (2003), e-government is the use of ICT and their application by the government 
for the provision of information and public services to the people. E-government is the subject of various international comparisons, as discussed by Khosrow-Pour (2005) or Bannister (2007). Most approaches aimed at assessing the overall and general state of e-government, and therefore assess the performance of government at all levels of the country: federal, regional and local. Only some approaches focus solely on the regional or local level, for example, KEeLAN (2002) and Sorensen (2000).

In the Czech Republic, transparency is increasingly discussed in the recent years and promoted by the development of e-government. The results, however, according to the analyses done for example by Ministry of the Interior, (MV , 2013a); MV ČR, 2013b; OECD; Šmídová, 2011) are not convincing. Evaluation of transparency by monitoring of information availability on the websites is not only the domain of national states. It is possible and desirable to be performed at the level of local bodies, as analysed on the local government websites in the EU countries (Pina, Torres, Royo, 2009) or as implemented in the municipal websites in the Slovak Republic in 2010, 2012 and 2014 (TIS, 2014).

In 2012 there was also analysed transparency in the Czech Republic at the level of higher local government units (FOM, 2012). Despite that fact, the local level still attracts much less attention than the national level. Also, the majority of research projects focus mostly on consequences of ICT use in the macro-scale of political and administrative processes (Bannister, 2007). However, the local and regional levels seem to be necessary because it is the closest level to the citizen. Most services are provided through local governments; as well participation in public life should be higher at the local level than at the national level. Therefore, it is necessary to provide a citizen with transparent information on public decision making as comfortable as possible.

\section{Research Methods and Data}

The aim of this paper is the evaluation of the availability of selected information about decision-making in municipalities with extended competences in the Moravian-Silesian region through municipal websites and assessment of participation tools for citizen involvement on the websites. The basic territorial self-governing unit in the Czech Republic is the municipality. In terms of administrative structure, municipalities with extended competences (ORP, municipalities III), are responsible for the widest range of government administration in delegated privileges and municipalities with authorized municipal office (municipality II). This is municipality to which state transfers some of its privileges, but not to such extent in which it is delegated to a municipality with extended competences. Status, rights and obligations of municipalities are defined in the Municipalities Act No. 128/2000. In the context of local bodies, the article focuses on municipalities with extended competences in the Moravian-Silesian region, defined by law regulation No. 314/2002. The analyzed websites of municipalities are listed on the website of RIS (2014).

As a methodology for transparency analysis, the methodology of Transparency International applied in Slovakia, supplemented by Rutgers-SKKU Municipal E-Governance methodology and methodology Website Attribute Evaluation System (WAES) was used. The methodology of Transparency International of Slovakia is aimed at assessing municipalities from the perspective of openness of public administration. The openness is evaluated in 11 areas: access to information, public participation, provision of public services, selling and renting of property, budget, subsidies and grants, flats and social facilities, personnel policy, ethics and conflict of interest, spatial planning and municipal enterprises and investment. For more detailed description of the methodology see on TIS (2012).

Rutgers-SKKU Municipal E-Governance methodology is based on Rutgers-SKKU E-Governance Performance Index. This is the instrument used to evaluate municipal web portals with respect to delivery of public service and citizen participation in governance. The instrument is composed of five components: security and privacy, usability, content, services and citizen participation (Holzer and Kim, 2006). The method is based on 100 measurements. Each component includes 20 measurements. Almost half of measurements is coded on a dichotomy of two-points (no, yes) representing un/availability of requested parameter on websites. Other measurements can be evaluated on a scale of 0 2 or $0-3$ points. WAES methodology is aimed at assessment of the content of websites. WAES is the binary tool. It analyses the content of the website in the context of specific detailed criteria (types of information, services, and web tools). The component in the content either exists or does not. As a result, a score of either "y" or " $n$ " is assigned to the specific criterion (Porebski, 2011). 
In the presented research, there selected only those measures (parameters) of introduced methodologies that assess the transparency of decision-making and publishing the results of the decision-making process and that assess the participation of the citizen in decision-making. For the purposes of exploratory analysis were selected all 22 municipalities with extended competences in the Moravian-Silesian region. Within these selected municipalities were visited websites and searched monitored information (parameters), which number is 20 . The search was carried out in accordance with a logical breakdown of websites within 20 minutes of an acceptable term for a web page; see Chen (2009) or Ziemba, Papaj and Descours (2014).

In case that the desired information was not found within the expected logical location in the menus and submenus of websites and even within the usage of the search function in a sustainable time, so the information was considered as unavailable. As archives, there are considered two years old data or more. The survey was realized in the year 2014. The searched information (20 parameters) are described in Table 1.

Table 1: Monitored parameters of municipal websites

\begin{tabular}{|c|l|}
\hline Parameter & \multicolumn{1}{|c|}{ Characteristic of monitored parameter } \\
\hline P1 & Electronic board and its archive \\
\hline P2 & Materials for the meeting of the council (publication before the meeting starts) and archives \\
\hline P3 & Minutes of the council and archives \\
\hline P4 & The audio / video recordings of council meetings and archive \\
\hline P5 & The procurement notice and archive \\
\hline P6 & The commission for evaluation of procurement and archive \\
\hline P7 & The results of procurement decisions and their archives \\
\hline P8 & Public tender for sale and rental of real property - offer, minutes of process and outcome, archives \\
\hline P9 & Annual final accounting and their archives \\
\hline P10 & The current budget and archive \\
\hline P11 & Supplier invoices \\
\hline P12 & Subsidies and grants - evaluation of applications and allocation decisions and their archives \\
\hline P13 & Land use plan \\
\hline P14 & Publication of e-mail addresses of employees \\
\hline P15 & Generally, binding regulations and city decrees on-line \\
\hline P16 & Free access to public information (no registration or passwords) \\
\hline P17 & Discussion on decision-making or message board with answers fromrepresentatives \\
\hline P18 & On-line voting and decision-making and its interim and final results \\
\hline P19 & Search tool \\
\hline P20 & Disclosure of information requests and archive \\
\hline
\end{tabular}

The parameters were determined based on the characteristics of the area of interest. The parameters should deeper characterize selected areas of analysis, which are the availability of information about the activities and decisionmaking processes in the municipalities (P1, P14, P16, P19), activity of the municipality council (P2, P3, P4), disclosure of procurement (P5, P6, P7), public funds treatment and real property management (P8, P9, P10, P11, P12), mandatory information (P13, P15, P20), participation of citizens (P17, P18).

\section{Results}

Monitored parameters P1 to P20 are in case of availability on the concrete website of municipality marked by "y", otherwise "n". Almost all of the monitored parameters are multi-valued (e.g., occurrence of current information and nooccurrence of the archive - the parameter value is then "y, n"). For multi-valued parameters can be only part of the information available for that category. Availability of information in this situation is determined proportionally (50 $\%$ ). 
The graph in Fig. 1 shows the availability of the monitored parameters. $100 \%$ availability of information for all monitored municipal websites were traced with seven parameters, which are Minutes of council meetings and their archives, Current budget and archive, published Land use plan, publication of e-mail addresses of employees, publication of generally binding regulations and city decrees on-line, free access to public information and Search Tool.

On the contrary, none of the monitored websites disclosed supplier invoices. E.g. in the Zlín region the first publisher of invoice on the internet was Kroměřiž city starting with the period from 1. 9. 2013. Very low is also information about committee's members that evaluate public procurement.

Spatial distribution of availability in the Moravian-Silesian region is showed in Fig. 2. Each website has been awarded a score from 0 to 20 depending on the availability of individual parameters. A minimum score of the worst municipal website from the viewpoint of transparency was 8.5, and the maximum score of the best municipal website was 15.2 . The median has value 12.25 .

Overall availability of information on monitored websites and the distribution of scores are depicted in Fig. 3. For each municipality, there was calculated an index of availability depending on all monitored parameters. This index was converted to a percentage value, where $100 \%$ availability means that all parameters are satisfied.

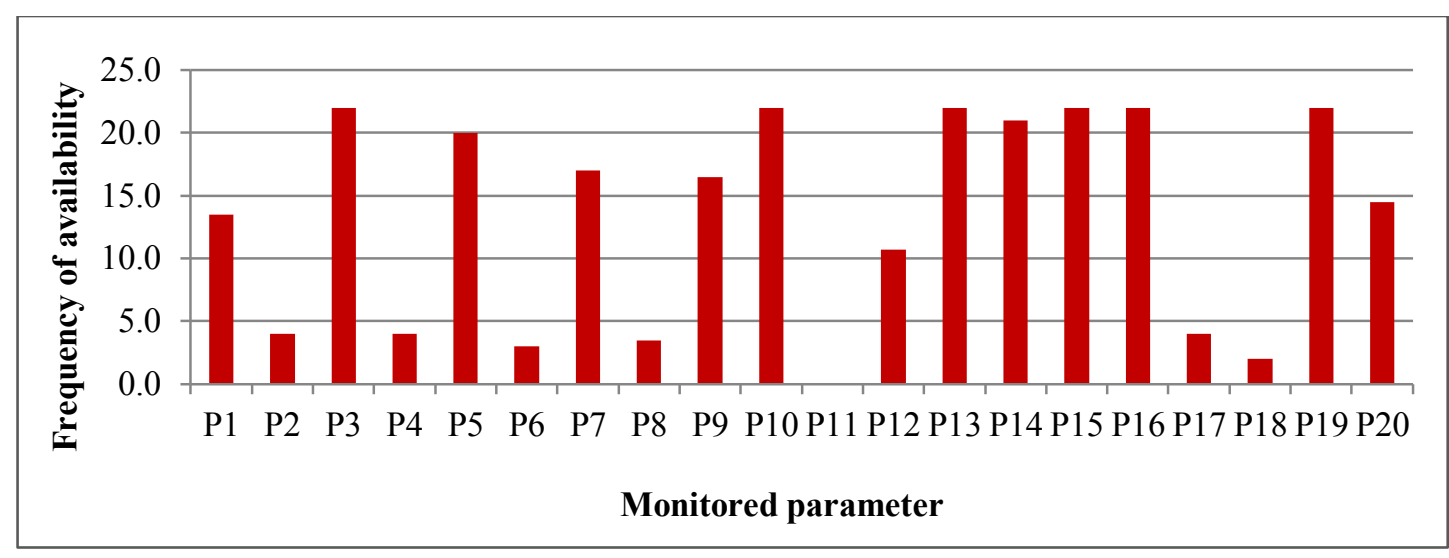

Figure 1: Monitoring parameters and frequency of their availability (2014)

Source: Own research on the websites of municipalities

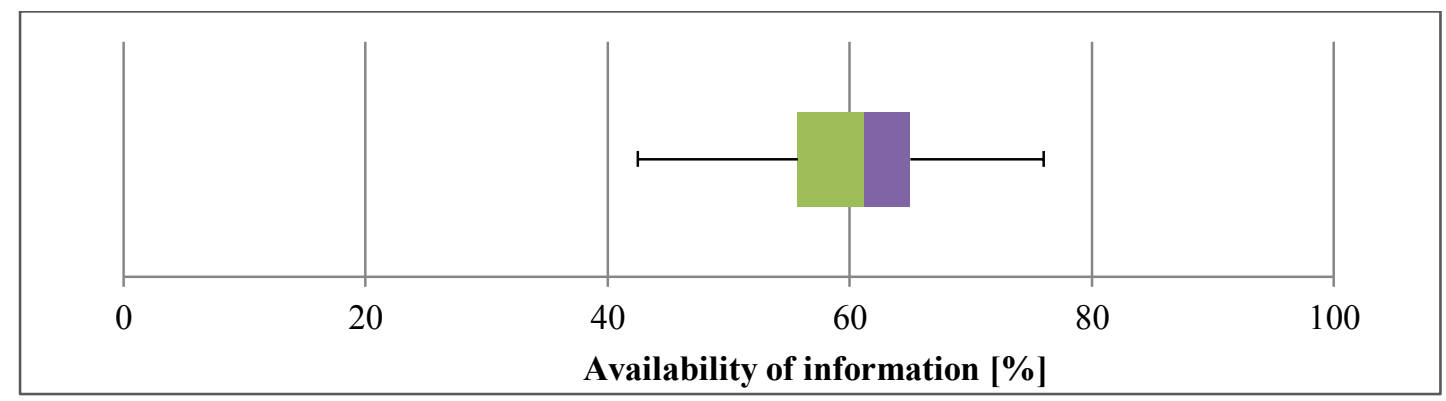

Figure 3: Availability of information on monitored websites (in \%)

Source: Own research on the websites of municipalities 


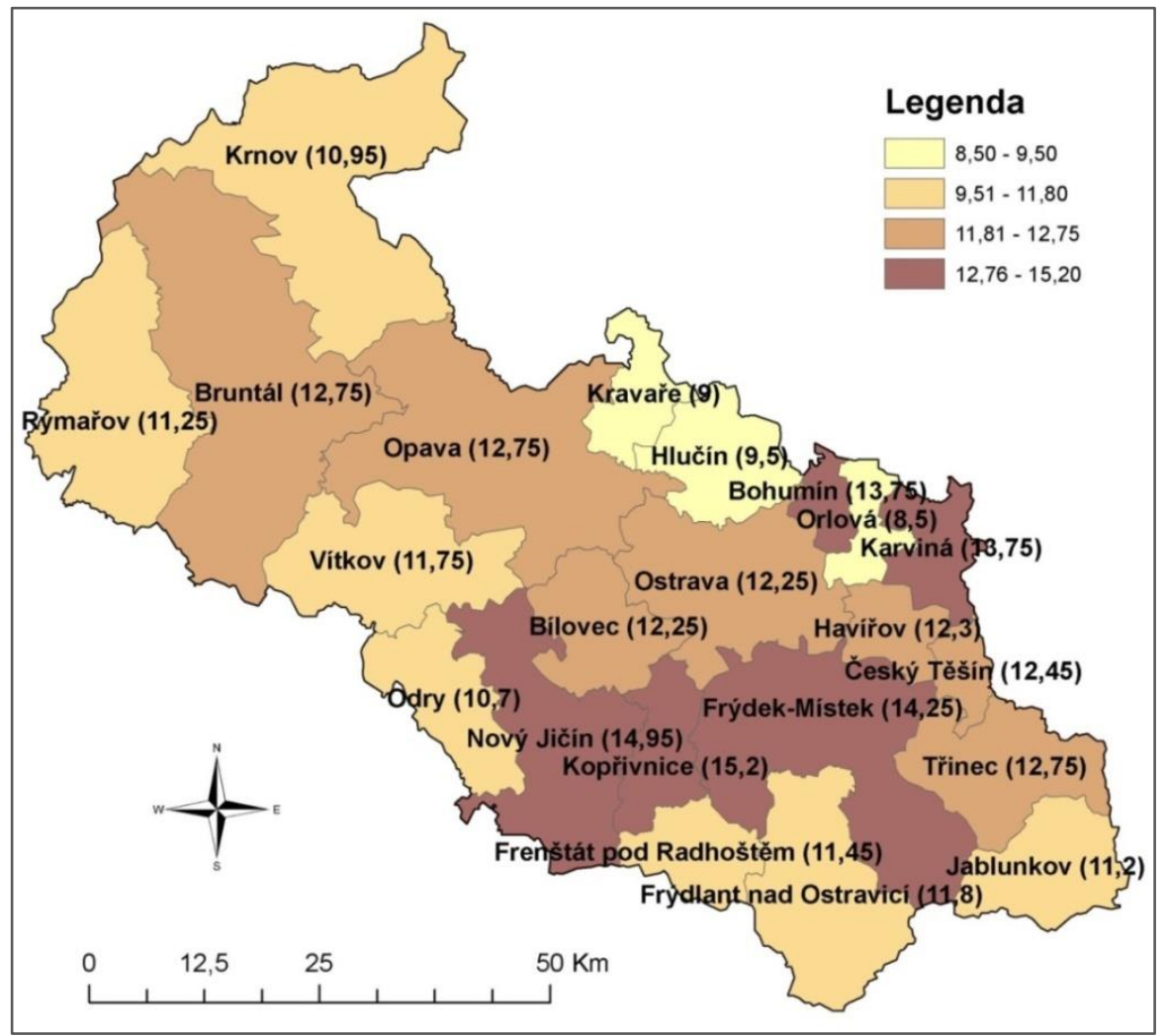

Figure 2: Spatial distribution of availability

Source: Own research on the websites of municipalities

In the box plot, there is shown, that $25 \%$ of municipalities offer availability at least $65 \%$ of monitored parameters. 75 $\%$ of municipalities offer availability better than $56 \%$. However, the most transparent website offers $76 \%$ of monitored parameters.

The following graph in Fig. 4 detailed shows the status of published information from the council meetings, where there were monitored three parameters: materials for meetings, minutes of meetings and multimedia records of the sessions. All were also monitored for archiving. The survey showed that no municipality publishes all information from the council meeting. In the best case there were published material for council meetings (publication before the meeting), and their archives, minutes of council meetings, and their archives, and audio / video recordings of council meetings without archives.

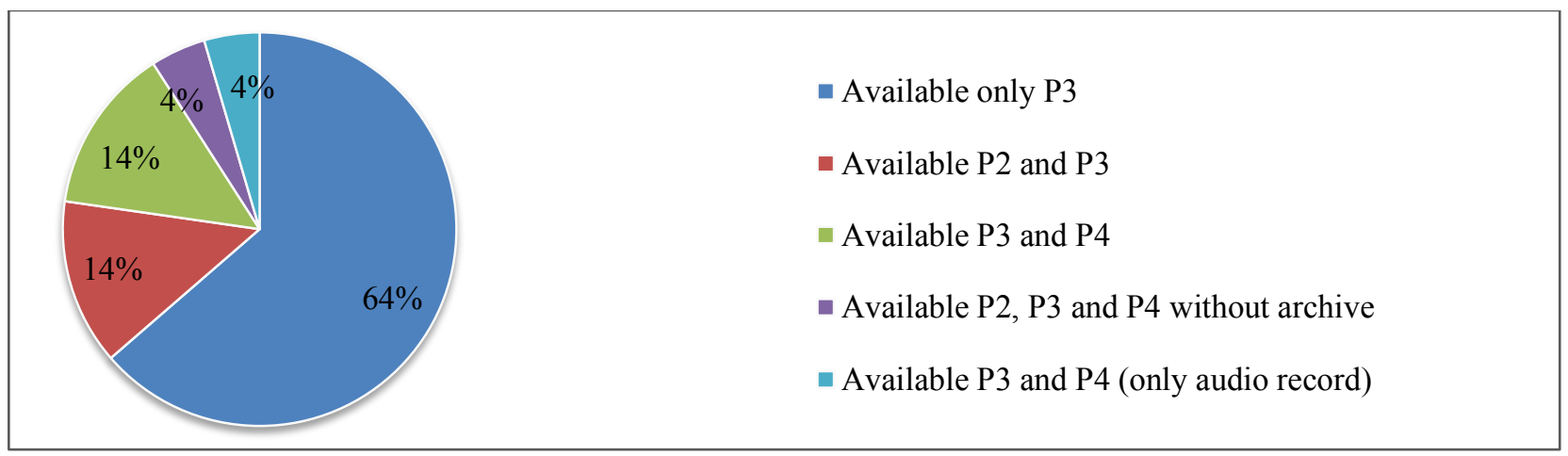

Figure 4: Availability of information from council meetings (in \%)

Source: Own research on the websites of municipalities 
The most common case was only publishing of minutes of council meetings and archives, the parameter P3 (64\%). Minutes of meetings and archives were otherwise available on all monitored websites, either alone or in combination with materials for meetings or multimedia records.

In the graph in Fig. 5 is depicted availability of information of public procurement. There were also observed three parameters: the procurement announcement, the evaluation committee and the results of the decision. Also the archiving of such information was monitored. The most common case was the occurrence of information about the procurement announcement and the results of the decision (64\% of visited pages). Only 3 municipalities offered complete information about public procurement.

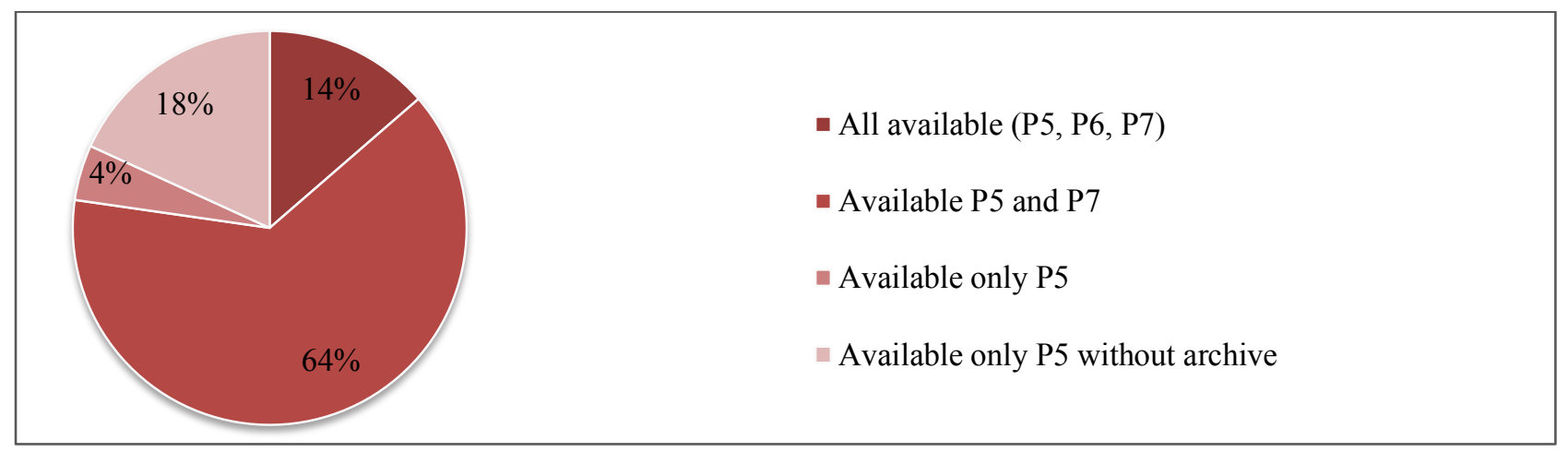

Figure 5: Availability of information about public procurement (in \%) Source: Own research on the websites of municipalities.

The following graph in Fig. 6 describes the status of the information publication about the management of public funds and real property. In all cases, there were published information about the current budget and its archives, most often in conjunction with the publication of the annual final accounting and subsidies and grants. None of the monitored websites contains information about the supplier invoices.

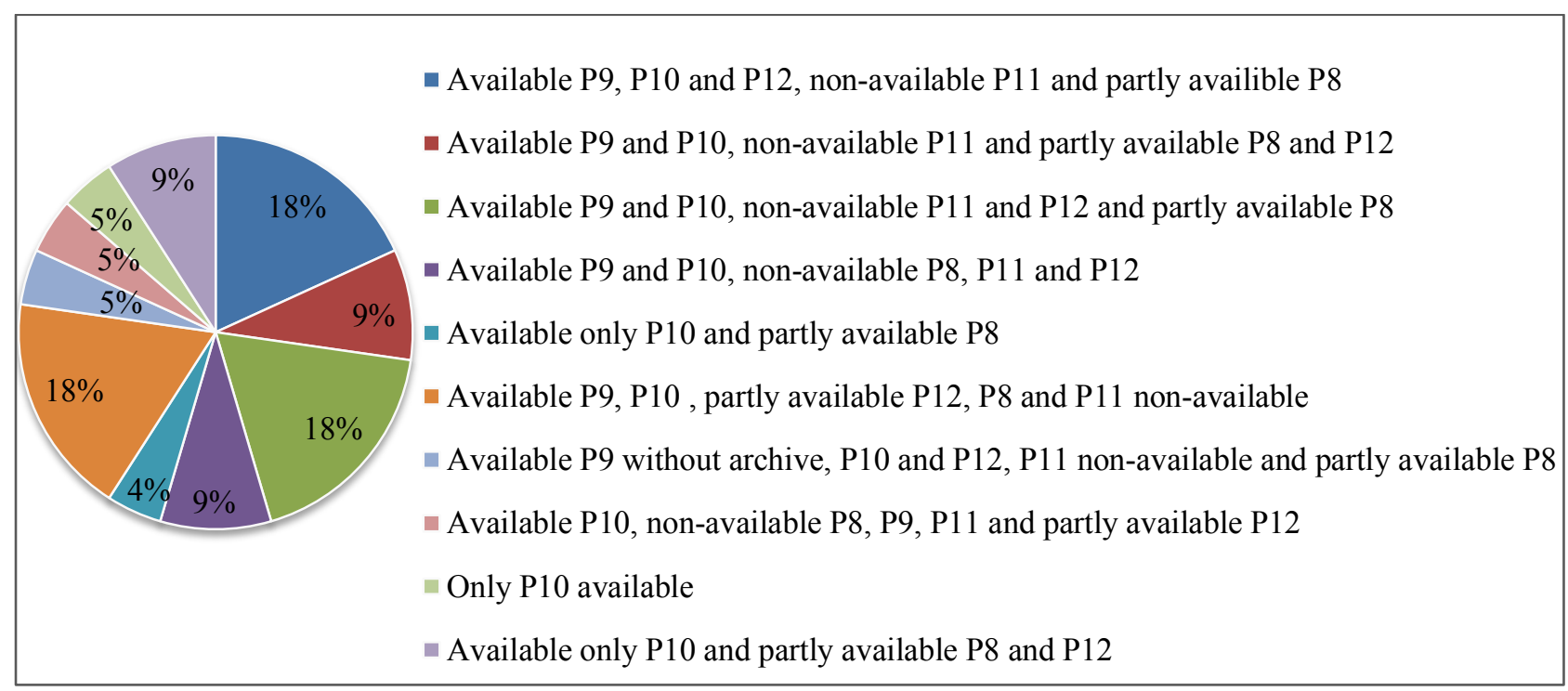

Figure 6: Availability of information about the financial management

Source: Own research on the websites of municipalities 
In the graph in Fig. 7, there is displayed the availability of information about activities and decision-making processes in municipalities. There were observed 4 parameters: electronic Bulletin Board and its archive, publication of e-mails of employees, free access to public information and availability of Search Tool. The occurrence of this type of information was ordinary on all monitored websites. All parameters were available on $23 \%$ of visited pages.

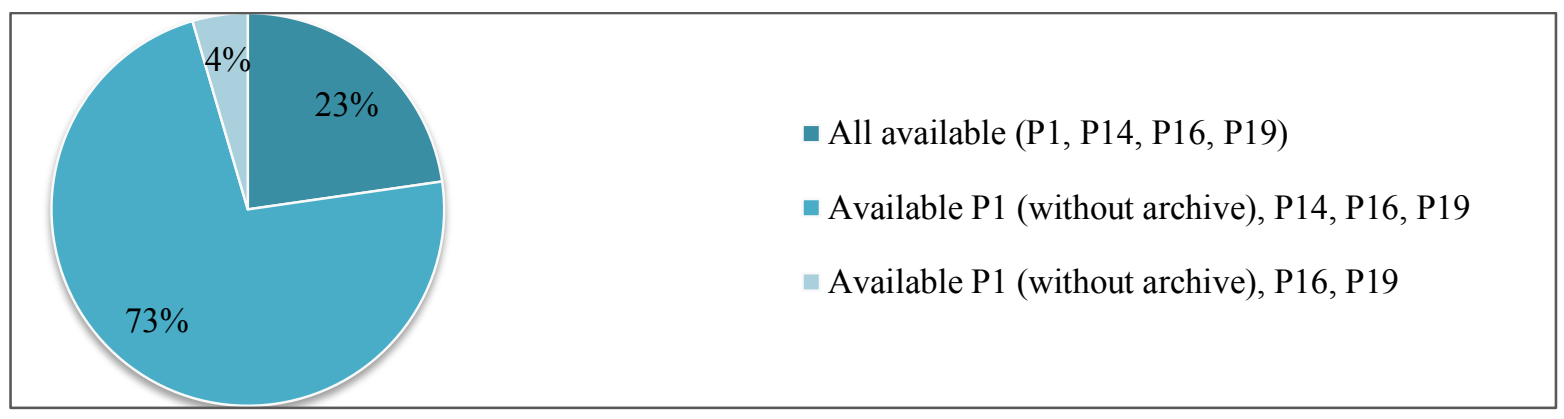

Figure 7: Availability of information about decision-making processes in municipalities (in \%)

Source: Own research on the websites of municipalities

Figure 8 shows the availability of mandatory published information. There were observed three parameters: availability of land use plan, generally binding regulations and city decrees on-line and disclosure of information requests and its archive.All parameters were available on $64 \%$ of visited pages.

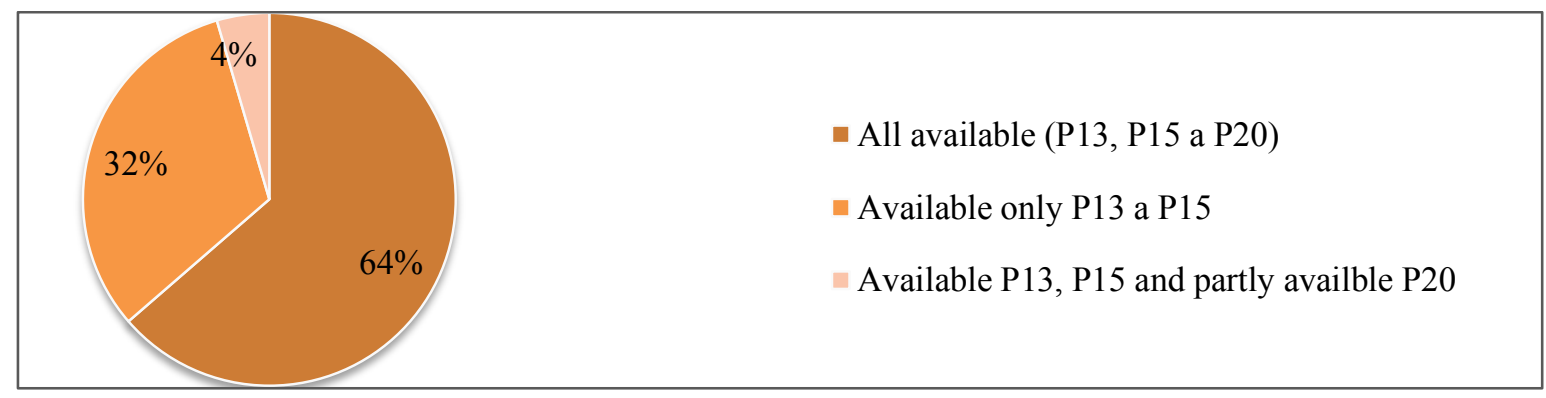

Figure 8: Availability of information about the mandatory information (in \%)

Source: Own research on the websites of municipalities.

The last graph in Fig. 9 describes the status of the participation of citizens. These parameters were found only rarely on the monitored websites. In $77 \%$ were available no parameters. Both parameters were available only in $4 \%$ of observed municipal websites.

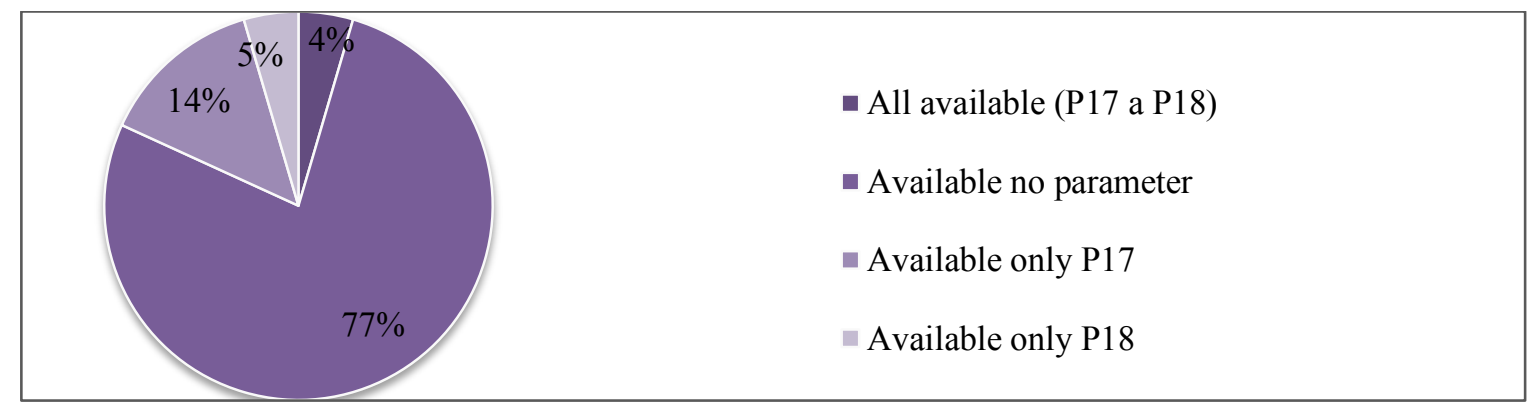

Figure 9: Availability of information about the participation of citizens (in \%)

Source: Own research on the websites of municipalities. 


\section{Interpretation and Discussion}

The article focused on the possibility of transparency evaluation by monitoring of information availability about decision-making and tools supporting the participation of citizens on the municipal websites. Based on this survey, it was found that the top rated municipalities offered $65-76 \%$ of the monitored parameters. Most websites (75\%) showed the availability of parameters greater than $56 \%$. The best-rated municipalities in the Moravian-Silesian region were Kopřivnice, Nový Jičín and Frýdek-Místek. Through the remote access, there was at least accessible information about the materials for council meetings, audio and video recordings of the council meetings and the commission for evaluation of procurement. None of the municipalities disclose the supplier's invoice and generally it was found very low participation of citizens in decision-making through electronic access.

The praxis of e-government in the Czech Republic is also annually evaluated within various competitions. The most famous competitions are "The Best" of the magazine Egovernment.cz, "Zlatý erb" and "National Award for Innovation in Public Administration" of the Ministry of Interior. Competitions results confirm that the practice of e-government in the Czech local government varied as summarized by Špaček (2012). Most frequent projects awarded were the projects promoting new communication tools of authorities with citizens or businesses (Skype, Call Centrum, SMS-/ MMS-ing) and also the projects improving public awareness of decision-making in the municipality (archived audiovisual recordings of Council meetings). In the category of new communication tools, in the competition in 2009, "Zlatý erb" awarded the municipality Semily (Liberec region) for allowing citizens to report defects and shortcomings via SMS. In the category of improving public awareness, the municipality Přibyslav (Vysočina region) was awarded for online broadcasts of Council meetings in 2009. The best-rated municipality in the Moravian-Silesian region in the year 2014 was the municipality Bruntál (VSO, 2014).

In the Czech Republic, the municipal websites were also evaluated within the initiative of Infoliga (OS, 2012). This initiative focused on the selected aspects of the praxis of the transparency principle. They assessed the municipalities according to the content of the municipal websites. The evaluation watched publication of municipal budgets, municipal board and the public procurement announcements. The best-rated municipalities in the Moravian-Silesian region in the last evaluated year, 2012, were the municipalities Kopřivnice and Nový Jičín, what confirm the results of own research (Fig. 2).

Similar to researches conducted on the local level of government in the Slovakia or Poland, our research on the second level of government in the Czech Republic, Moravian-Silesian region has identified low participation of citizens in a decision-making process. For example, Porebski (2012) described in the year 2009 that only $13.7 \%$ availability of discussion forums on the polish municipal websites. In our research, the availability of online discussion forums on the monitored websites was $14 \%$. Also, TIS (2014) evaluated the state of transparency at municipal websites in the year 2010, 2012 and 2014. The level of citizen participation was evaluated to be very low. The shortcomings were found in the area of publication of Council meetings and insufficient tools for participation in decision-making.

This research has pointed out further possibilities for the analysis of transparency in the future. The set of monitored parameters can be extended by, for example, the publication of minutes of the municipal board, posting responses of a council to citizens or a list of contracts. Also, the monitored parameters can be distinguished by legislative binding force (obligatory and optional). Obligatory disclosures are regulated by Act No. 106/1999. The same analytical framework can be applied not only for the municipalities with extended competences but also for other levels of government. The further research is needed to assess if the principle of transparency is respected on the local level of government.

\section{Conclusion}

The article evaluates the praxis of transparency principle adoption in the Czech e-government. We monitored selected information about decision-making and tools supporting the participation of citizens on the local level of government in the Moravian-Silesian region published on the municipal websites. Based on this survey, the rate of information availability in the monitored area and the municipal websites were ranked according to the availability of information. Some municipal websites were very confusing and it was very difficult to find required information. For this reason, it 
would be appropriate to introduce some kind of standardization of municipal web pages so that the important data are easily obtainable.

The area of e-participation has not been analyzed in the Czech research sufficiently yet, but the actual results of websites evaluation in the Czech Republic (FOM, 2012 and OS, 2014) points out the low level of citizen participation in the decision-making process. The communication with citizens and citizen involvement in various discussions and decision-making should be one of the main roles of the city website. Participation of citizens should be encouraged by the implementation of on-line discussion and thematic forums. Leaders of municipalities should participate in these discussions. Citizens should be involved in decision-making through electronic elections or surveys. The results of these surveys should be published online.

\section{References}

- Bannister, F., (2007) The curse of the benchmark: an assessment of the validity and value of e-government comparisons, International Review of Administrative Sciences, Vol. 73, No. 2, pp. 171-188. CrossRef

- Chen, S-Y. and Young, R.S. (2009) Take Your Time First, Time Your Search Later: How College Students Perceive Time in Web Searching, In Proceedings of the American Society for Information Science and Technology, Vol 46, No. 1, pp. 1-19. CrossRef

- European Commission. (2003) Interconnecter l'Europe: l'importance de l'interopérabilité des services de l'administration électronique. [online]. Luxembourg: European Commision. [cit. 1.2.2015]. Available at: < http://ec.europa.eu/idabc/servlets/Doc83c4.pdf?id=1677>.

- FOM - Fond Otakara Motejla (2012). Hodnocení krajů. [online]. [cit. 5.4.2014]. Available at: $<$ http://www.hodnocenikraju.cz/cz/sets/kraje-2012/about>.

- Gil-García, R.J. and Helbig, N. (2006) Exploring e-government benefits and success factors. In Encyclopedia of Digital Government, A. V. Anttiroiko and M. Mälkiä, Eds., Hershey: Idea Group Reference, Vol. 2, pp. 803-811. CrossRef

- Gupta, B., Dasgupta, S. and Gupta, A. (2008) Adoption of ICT in a government organization in a developing country: an empirical study, Journal of Strategic Information Systems, Vol. 17, No. 2, pp. 140-154. CrossRef

- Holzer, M. and Kim, S-T. (2006) Digital Governance in Municipalities Worldwide (2005): A Longitudinal Assessment of Municipal Websites Throughout the World. New Jersey: National Center for Public Productivity. 2006. ISBN 094294206 X.

- KEeLAN. (2002) ELANET. [online]. [cit. 2.4.2014]. Available at: <http://www.elanet.org/aboutus/projects/keelan>.

- Khosrow-Pour, M. Practicing E-Government: A Global Perspective. Hershey: Idea Group Publishing, 2005. ISBN 1-59140-638-2. CrossRef

- Marek, J. (2006) Evropské principy dobré veřejné správy, In Principy dobré správy, D. Hrabcová Eds., Brno: Masarykova univerzita, pp. 91-95. ISBN 80-210-4001-7.

- Michel, H. (2005) E-administration, e-government, e-governance and the learning city: A typology of citizenship management using ICTs, The Electronic Journal of e-Government, Vol. 3, No. 4, pp. 213-218.

- MV ČR. (2013a) Vyhodnocení implementace Strategie Smart Administration. [online]. [cit. 4.4.2014]. Available at: <http://www.smartadministration.cz/soubor/vissa-final-pdf.aspx>.

- MV ČR. (2013b). Analýza aktuálního stavu veřejné správy. [online]. [cit. 4.4.2014]. Available at: $<$ http://www.mvcr.cz/soubor/analyza-aktualniho-stavu-verejne-spravy-pdf.aspx>.

- OECD. (1999) European Principles for Public Administration. SIGMA Papers No. 27. Paris: OECD Publishing, Januar 1999. Retrieved from: <http://www.oecdilibrary.org/docserver/download/5kml60zwdr7h.pdf?expires=1432595202\&id=id\&accname=guest\&checksum =0B30B44EF8F3C25E480239BE989AB8E1>.

- OS - Otevřená společnost. (2014) Infoliga. Projekt otevřené společnosti. [online]. [cit. 4.5.2014]. Available at: $<$ http://www.infoliga.cz/ $>$.

- Pina, V., Torres, L. and Royo, S. (2009). E-government evolution in EU local governments: a comparative perspective, Online Information Review, Vol. 33, No. 6, pp. 1137-1168. CrossRef 
- Porebski, L. (2011) Evaluating the Development of eGovernment Systems: The Case of Polish Local Government Websites, Proceedings of the 11th european conference on e-government, M. Klun, M. Decman, T. Jukic Eds., Ljubljana, pp. 475-481. ISBN 978-1-908272-00-3.

- RIS - Regionální informační servis. (2014) Správní členění kraje. [cit. 8.1.2014], Available at: $<$ http://www.risy.cz/cs/krajske-ris/moravskoslezsky-kraj/verejna-sprava/spravni-cleneni>.

- Šmidová, Z. (2011) Public Spending Efficiency in the Czech Republic: Fiscal Policy Framework and the Main Spending Areas of Pensions and Healthcare. Paris: OECD Publishing, December 2011. 43 pp. ISSN 18151973.

- Sorensen P. and Abildgaard, F. (2000) Infoville, Socio-economic impact report. November 2000. [cit. 8.1.2015], Available at: < http://digitalsites.infoville.net/index.htm>.

- Špaček D. (2012). eGovernment-cíle, trendy a př́ístupy k jeho hodnocení. Praha: C. H. Beck. ISBN 978-807400-261-8.

- TIS - Transparency International Slovensko. (2014) Otvorená samospráva 2014. [online]. [cit. 5.4.2014], Available at: $<\mathrm{http}: / /$ samosprava.transparency.sk/sk/>.

- Vaníček, Z. et al. (2011). Právní aspekty eGovernmentu v ČR. Praha: Linde Praha. ISBN 978-80-7201-855-0.

- VSO - Veřejná správa online. (2014) Výsledky celostátního kola soutěže Zlatý erb 2014. [online]. [cit. 10.1.2014], Available at: <http://zlatyerb.obce.cz/vismo/dokumenty2.asp?id_org=200005\& id=1234>.

- Zákon č. 106/1999 Sb., o svobodném př́stupu k informacím. [cit. 8.1.2015], Available at: < http://www.mkcr.cz/scripts/detail.php?id=325>.

- Zákon č. 128/2000 Sb. o obcích. [cit. 8.1.2015], Available at: < http://portal.gov.cz/app/zakony>.

- Zákon č. 314/2002 Sb. o stanovení obcí s pověřeným obecním úřadem a stanovení obcí s rozšířenou působností. [cit. 8.1.2015], Available at: < http://www.psp.cz/sqw/sbirka.sqw>.

- Ziemba, E., Papaj, T. and Descours, D. (2014) Assessing the quality of e-government portals - the Polish experience. In Proceedings of the 2014 Federated Conference on Computer Science and Information Systems. Warsaw: IEEE, 2014. Vol. 2, pp. 1259-1267. ISBN 978-83-60810-58-3. CrossRef 